\title{
Marek Tomaszewski: Profetyczne akcenty prozy Brunona Schulza
}

Przypomnijmy na wstępie refleksję wyrażoną przez Schulza w formie eseistycznej w Mityzacji rzeczywistości: „Poezja dochodzi do sensu świata anticipando, dedukcyjnie, na podstawie wielkich i śmiałych skrótów i przybliżeń. Wiedza dąży do tego samego indukcyjnie, metodycznie, uwzględniając cały materiał doświadczenia. W gruncie rzeczy i jedna, i druga zdążają do tego samego"1. Ważny jest zatem sam kierunek dociekań Schulzowskich, który wyraża się określoną postawą antycypacyjną. Aby zobrazować to zagadnienie, skupię się głównie na Sklepach cynamonowych, choć nietrudno zapewne dopatrzyć się podobnych wybiegających naprzód eksperymentów w innych tekstach Schulza, takich choćby jak Kometa, Martwy sezon czy też Noc lipcowa.

Jak dobrze wiemy, zatopiony w ezoterycznych praktykach Jakub, ojciec Józefa, podjął się ambitnego dla ludzkiej wiedzy zadania, rozwijając program „wtórej demiurgii”, to znaczy drugiej generacji stworzeń, owej generacji, która stanąć miała w otwartej opozycji do panującej epoki. Jego zainteresowanie dla skrzydlatych osobników wyrażało się przede wszystkim chęcią spenetrowania „odmiennych form życia” tkwiących $\mathrm{w}$,nie wypróbowanych rejestrach bytu”. Założenie to nie było zatem całkiem zgodne ze znanym nam już dobrze dzisiaj procesem klonowania, chociaż powstanie rozdziałów-opowiadań składających się na Sklepy cynamonowe sięga roku 1933, a zatem tylko o rok wyprzedza nadanie medycznego Nobla Hansowi Spermanowi (1934), który kilka lat później (w roku 1938) zaproponował przełomowe doświadczenie usunięcia jądra komórkowego niezapłodnionej komórki jajowej i zastąpienia go jąpowściągliwość Jakuba drem z komórki rozwiniętego zarodka. Najwidoczniej Jakub nie posuwa się tak daleko jak niemiecki embriolog w swoich odkrywczych działaniach i nie chodzi mu bynajmniej o tworzenie za pomocą skrzydlatych egzemplarzy idealnej kopii na podstawie oryginału. Przeciwnie - podkładanie zapłodnionych wcześniej egzotycznych jaj ptasich kurom belgijskim pozwala mu obserwować wykluwanie się nieoczekiwanych pączków życia, przemieniających się w „prawdziwe dziwotwory”, ornitologiczne monstra i wybryki natury, napełniające jego pokój kolorowym trzepotem.

1 B. Schulz, Opowiadania. Wybór esejów i listów, oprac. i wstęp J. Jarzębski, Wrocław-Warszawa-Kraków 1989, BN I, 264, s. 367. Wszystkie adnotacje dotyczące stron pochodzą z tego wydania. 
w kierunku futurum
Działaniom takim nie przyświeca żadna naukowa racjonalność, opierająca się na ścisłej wiedzy. Jednakowoż ogromny rozwój genetyki oraz próby stworzenia zwierząt $\mathrm{z}$ komórek wyizolowanych $\mathrm{z}$ wczesnych zarodków, transfer jądra komórkowego i inne tego rodzaju naukowe osiągnięcia wskazują z perspektywy naszej epoki na niebywałą intuicję i twórcze, quasi-profetyczne wychylenie prozy Schulza w kierunku futurum. Nie zapomnę nigdy mojego zdziwienia, gdy udając się dziesięć lat temu samochodem na seminarium o prozie Schulza ze studentami we Francji, słuchałem, jak tamtejsze radio powracało niezmordowanie do tematu genetycznych krzyżówek, zapytując nieustannie o moralną i filozoficzną podstawę takich działań. Było to wtedy jedno z głównych zagadnień, które roztrząsali naukowcy i filozofowie. Dokąd wolno nam eksperymentować, gdzie leży nieprzekraczalna granica integralnego kształtu ludzkiego lub zwierzęcego gatunku? - zapytywali oni gorączkowo, szukając jądra prawdy. Wtedy to skojarzyłem sobie po raz pierwszy, do jakiego stopnia artystyczne dywagacje Schulza wyprzedzały dylematy jego własnej epoki. Jerzy Jarzębski, walcząc $\mathrm{z}$ archaicznym wizerunkiem drohobyckiego pisarza, dochodzi również do wniosku, że nie tylko nie stał on po stronie przeszłości, ale - przeciwnie - starał się wielokrotnie w swej twórczości wybiegać naprzód: „Zawsze intrygowała mnie zaświadczona przez przyjaciół namiętność Schulza do nauk ścisłych: matematyki, fizyki, jego znajomość technicznych nowinek. [...] o problemach najnowszej nauki Schulz myślał bardziej serio, niżby się zdawało"2 . Jest rzeczą oczywistą, że świat uczonego badacza i artysty nie jest z tej samej materii. Jednakowoż ornitologiczna impreza Jakuba wpisuje się trwale w narracyjną strukturę Sklepów cynamonowych, stanowiąc coś na kształt klamry spinającej poszczególne sekwencje opowiadania. Ptaki, które zajmują centralne miejsce w początkowej części Sklepów cynamonowych, zostają wprawdzie tymczasowo wycofane $\mathrm{z}$ tekstu po tragicznych dla „metafizycznego prestidigitatora” generalnych porządkach na strychu, kiedy to „tuman skrzydlaty” unosi się gdzieś w powietrze, w nieokreśloną dal, lecz cień problematyki wynikłej z tego zdarzenia zawisa od tego momentu nad opowiadaniem, przygotowując teren do jego ostatecznego rozwiązania.

Estetyczna suwerenność literatury polega na tym, że zamazuje się rozróżnienie między regułami kształtowania fikcyjnych opisów a zasadami zjawisk rzeczywistości empirycznej. „Poezja - jak słusznie zauważa francuski filozof Jacques Rancière (a przecież „poetycki model prozy” Schulza bliski jest poezji!) - nie musi tłumaczyć się z prawdy, ponieważ nie jest 
w swojej istocie zbudowana ze świadectw lub obrazów, ale z fikcji, to znaczy z pewnego układu czynów i zdarzeń". W moim odczuciu proza Schulza doskonale ilustruje ten punkt widzenia. Przypomnijmy także, iż według Jacques’a Rancière’a „świadectwo i fikcja wywodzą się z tego samego reżimu sensu [...]. Realne musi przybrać postać fikcji, aby dało się o nim myśleć"3.

Otóż analogicznie ostatnia scena ostatniego rozdziału, rozgrywająca się w sakralnej przestrzeni sklepu Ojca i przyrównana do biblijnej krainy Kaanan, wprowadza nutę szczególnego, wychylonego ku przyszłości katastrofizmu. Kiedy drohobycki kupiec, spotężniały w gniewie, miota się na barykadzie pościeli, ściany sklepu zamieniają się nagle w pejzaż Ziemi Świętej, pełen jezior i zamglonych dali. Opisany w tej scenerii końcowy fragment Sklepów cynamonowych, w którym odbywa się lot niesamowitych ptaków, przynosi ów sekretny klucz do tajemnicy, otwierający głęboki sens opowiadania. Widoczny skutek wcześniejszych „heretyckich manipulacji” Jakuba, scena powrotu ptactwa przepędzonego niegdyś przez Adelę, łączy w sobie bowiem zarówno profetyczne naukowe spekulacje, jak i pewne pojęcia z zakresu praprzyczyny, inicjalnej kreacji. Chodzi tutaj przecież o quasi-fantastyczne latające stwory, będące rezultatem wykoncypowanej przez Jakuba „wtórej genezy”, opartej na ryzykownych, niemających precedensu scientycznych improwizacjach badacza: „Wracało teraz, zwyrodniałe i wybujałe, to sztuczne potomstwo, to zdegenerowane plemię ptasie, zmarniałe wewnętrznie. [...] Było to jakby muzeum wycofanych rodzajów, rupieciarnia Raju ptasiego"4.

„W Wielkim Sezonie, który czasem występuje w trzynastych, fałszywych miesiącach, wszystko, co ma się zdarzyć, zdarza się w wielkiej skali, wszystko, co zapomniane, powraca jako kataklizm, i wszystko, co jest marzeniem, pojawia się jako koszmar"- przypomina nam Jan Gondowicz w tekście Powrót wielkich ptaków ${ }^{5}$. Nieprzypadkowo nad zagadnieniem ptaków pochylił się też Piotr Millati w Słowniku schulzowskim. Aliści owe wypchane mięsem kręgowce, wyciągające do Mistrza idiotycznie powiększone łby, wcielają właśnie bardzo konkretnie w czyn wypracowaną przez niego teorię generatio aequivoca, stając się namacalnym rezultatem twórczego zamysłu, który najwidoczniej uległ rozpadowi, degradacji, ujawniając tym samym okrutnie asynchroniczną dewiację fruwającej fauny. A przecież gdy się odniesiemy, tytułem porównania,

3 J. Rancière, Dzielenie postrzegalnego. Estetyka i polityka, przeł. M. Kropiwnicki i J. Sowa, Kraków 2007, s. 101, 103 i 104.

4 B. Schulz, Noc wielkiego sezonu, s. 103.

5 J. Gondowicz, Powrót wielkich ptaków, „Schulz/Forum” 1, 2012, s. 12. 
do ikonografii chrześcijańskiej, ptaki jawią się tam jako symbole chybkości myśli i wyobraźni, kojarzone z wyższymi stanami istnienia, wolnymi od ziemskiej ociężałości. W grece już samo to słowo mogło stać się synonimem przepowiedni i posłania z nieba. Jak wytłumaczyć to odwrócenie pojęć? Wszakże jest oczywiste, że mamy tutaj do czynienia z poniżeniem, uprzedmiotowieniem skrzydlatych tworów, sprowadzeniem owych symbolicznych wysłanników nieba do roli niedołężnych i ociężałych manekinów.

Niełatwo tutaj o prostą i jednoznaczną interpretację. Wydaje się, iż oprócz paranaukowych pytań dotyczących samej istoty gatunku, które stawia nam tekst Schulza nie tyle w kategorii fikcji wyjaśniającej, ile w kategorii fikcji odkrywającej i wybiegającej naprzód na drodze profetycznych skojarzeń odnajdujących naukowy akord w naszej epoce, wplata się w zakończenie Sklepów cynamonowych jeszcze jeden ważny wątek, który zwraca uwagę na to, co nazwałbym syndromem metafizycznego i antropologicznego lęku o istoty odrębne i kalekie ${ }^{6}$. Dramatyczny akcent kolizji unormowanego świata $\mathrm{z}$ wyalienowanymi ofiarami genetycznego eksperymentu wyraża się najlepiej w tej oto scenie:

„Ale te papierowe, ślepe ptaki nie mogły już poznać ojca. Na darmo wołał na nie dawnym zaklęciem, zapomnianą mową ptasią, nie słyszały go i nie widziały.

Nagle zagwizdały kamienie w powietrzu. To wesołki, głupie i bezmyślne plemię, jęły celować pociskami w fantastyczne niebo ptasie.

$\mathrm{Na}$ darmo ojciec ostrzegał, na darmo groził zaklinającymi gestami, nie dosłyszano go, nie dostrzeżono. I ptaki spadały. Ugodzone pociskiem, obwisały ciężko i więdły już w powietrzu. Nim doleciały do ziemi, były już bezforemną kupą pierza" 7 .

Dlaczego niewydarzone, nieodpowiadające powszechnie przyjętym ptasim wzorcom latające upierzone okazy skazane są na zagładę? Co mają oznaczać te wstrząsające obrazy brutalnego unicestwienia? Stawiając te pytania, przekraczamy niejako świat doświadczeń Schulza - autora Sklepów cynamonowych i zbliżamy się nieuchronnie do Schulza wchodzącego powoli w mroczną epokę mającą niechybnie zmienić oblicze Europy. Można powiedzieć, że dość wcześnie, bo już w 1933 roku, zwyrodniałe ptactwo postrzegane jest przez wizjonera $z$ Drohobycza, $z$ pewnym czasowym wyprzedzeniem, jako prowokacyjne wyzwanie dla tych wszystkich, którzy już wkrótce stanąć mieli na straży genetycznej dosko-

6 O różnicy między "fikcjami wyjaśniającymi" a "fikcjami odkrywającymi” pisał wyczerpująco Wolfgang Iser w studium Czym jest antropologia literatury. Różnica między fikcjami wyjaśniającymi a odkrywającymi, przeł. A. Kowalcze-Pawlik, „Teksty Drugie” 2006, nr 5, s. 33.

7 B. Schulz, Noc wielkiego sezonu, s. 103. 
nałości i czystości rasy jako takiej ${ }^{8}$. Ukamienowanie (lapidacja) to, wraz z rozszarpaniem, najstarsza kara śmierci, zadawana tym, którzy łamali reguły religijne lub plemienne. Dzisiaj jeszcze ta forma uśmiercania cieszy się uznaniem w krajach takich jak Iran, Somalia, Nigeria, Arabia Saudyjska i Zjednoczone Emiraty Arabskie. Odszczepienie (lub „odchylenie", by użyć terminologii Jakuba) od określonego formatu ptasiego, które obserwujemy w prozie Schulza (Ojcu marzyło się od początku o wielkich ptakach), anonsuje zatem zawczasu odszczepienie (odchylenie) od analogicznie zakodowanego w wyobraźni społecznej skodyfikowanego formatu ludzkiego. Rzecz wprawdzie dotyczy świata zwierzęcego, ale barbarzyński wandalizm jest faktycznie dziełem tych, których autor nazywa „wesołkami”, „głupim i bezmyślnym plemieniem”, przy czym słowo „plemię” określa wspólnotę, grupę społeczną lub etniczną, ród, szczep, ewentualnie frakcję narodową. Wśród tak pojętej społeczności nie ma, jak widać, miejsca dla zaprzańców, katechumenów, nieudaczników, połamańców i kuternóg, wcielających w życie filozofię ,inności”. Przyznajmy, że proroczy charakter sceny spadających na ziemię poranionych ptaków wprowadza w nasze umysły pewien dyskomfort i zakłopotanie. Wiemy bowiem, że ten typ przemocy wpisany jest niestety w geny ludzkości i że może on w każdej chwili i w każdym miejscu na świecie reaktywować okrutną spiralę nienawiści.

Tak oto rysują się w prozie Schulza analogie i zbieżności między reprezentacją fikcyjną a nauką (wyjaśniającą) - w tym ostatnim przypadku nauką historyczną. Ów dar wyprzedzania obiektywnych faktów rejestrowanych przez Historię, wpisany niejako w strukturę dzieła, jest wyrazem niepospolitej ekstrapolacji i wyczucia nadchodzących problemów. Mówi on nam o silnym związku literackości z historycznością, który stanowi skądinąd podstawę dociekań Jacques’a Rancière’a, przekonanego o tym, że jedynie teksty literackie posiadają zdolność „rekonfigurowania mapy tego, co postrzegalne"9. Jest tak, ponieważ potężny ruch gry tekstowej, generujący różne możliwości narracyjne, zapobiega wykształceniu określonej intencji, określonego posłania. To właśnie Wolfgang Iser $\mathrm{w}$ innym swoim eseju, zatytułowanym Zew tekstu, zwraca uwagę, że tym, co określa najlepiej tekst literacki, jest właśnie jego zdolność do nieujawniania własnych intencji: „To, co najważniejsze, jest przemilcza-

8 Koledzy Andrzeja Chciuka pytali Brunona Schulza, dlaczego tak uparcie rysuje i maluje brodatych Żydów. „Bo to wszystko wkrótce zniknie z powierzchni ziemi, zginie, zmiecione burzą, jaka idzie. Trzeba to zanotować, malować, rozumiesz, dlatego!" - odpowiedział (A. Chciuk, Atlantyda, Opowieść o Wielkim Księstwie Bałaku, Londyn 1969, s. 63). Świadczyłoby to o tym, że pewne fikcyjne obrazy mogły rzeczywiście odnaleźć intuicyjne potwierdzenie w opiniach ich twórcy.

9 J. Rancière, op. cit., s. 105. 
nie-

apo-

-fantyczność ne. Jeśli przyjąć, że tak jest, to gdzie należy szukać intencji uruchamianej przez tekst? W wyobraźni czytelnika”. Na koniec niemiecki antropolog literatury podsumowuje: „Tekst literacki, czerpiąc własną rzeczywistość nie w świecie przedmiotów, lecz w wyobraźni czytelnika, jest szczególnie uprzywilejowany w stosunku do innych tekstów, które chwalą się tym, iż przytaczają jakiś sens lub wypowiadają jakąś prawdę, krótko mówiąc - tych wszystkich tekstów, które posiadają charakter apofantyczny (twierdzący)"10.

Być może główną cechą prozy Schulza jest właśnie jej wszechobecna nieapofantyczność. Cecha ta stawia przed nami ciągle nowe zadania interpretacyjne. „Marzenie, a więc sztuka, jest istotniejsze od działania, $\mathrm{w}$ marzeniu wszystko jest możliwe, $\mathrm{w}$ działaniu natomiast ze wszystkich możliwości pozostaje zrealizowana tylko jedna" - zauważa słusznie Michał Paweł Markowski, pochylając się nad twórczością Fernanda Pessoi 11. To samo można by z powodzeniem powiedzieć o prozie Brunona Schulza. Rzeczywiste jest w niej marzenie, choć marzyciel skupia się na tym, co nie istnieje naprawdę, lecz co mogłoby zaistnieć w przyszłości. Mnogość możliwości utopijnej fantazji i wariantów narracyjnych, które odsłania tego typu literatura, nie stanowi bynajmniej przeciwieństwa istniejącej, rozpoznawalnej przez nas rzeczywistości, ale raczej buduje obszar zawieszenia między tym, co było, a fascynującą tajemnicą tego, co będzie. Paradoksalnie impuls przekraczania granic tego, co empirycznie dostępne i namacalnie sprawdzalne, zaostrza nasze pragnienie samoświadomości i dodaje nam wiary w nieredukowalny i jakże pożyteczny wymiar naszej wyobraźni.

10 W. Iser, L'appel du texte. L'indétermination comme condition d'effet esthétique de la prose littéraire (Zew tekstu. Nieokreśloność jako warunek estetycznego oddziaływania prozy literackiej), tłumaczył z niemieckiego na francuski V. Platini, Paris 2012, s. 57. Wydanie polskie nosi tytuł Apelatywna struktura tekstów. Nieokreśloność jako warunek oddziaływania prozy literackiej, „Pamiętnik Literacki" LXXI, 1980, nr 1.

11 M.P. Markowski, Życie na miarę literatury, Kraków 2009, s. 278. 